ISSN: 2617-9415 (Online)

CODEN : ESSDAX

\title{
RESEARCH ARTICLE \\ RESEARCH ON THE APPLICATION OF PROBLEM-BASED TEACHING IN MATHEMATICS EDUCATION
}

\author{
Yin Xin-Yu \\ Xi'an University of Science and Technology \\ *Corresponding Author Email: zumingli2@gmail.com
}

This is an open access article distributed under the Creative Commons Attribution License, which permits unrestricted use, distribution, and reproduction in any medium, provided the original work is properly cited.

\section{ARTICLE DETAILS}

\section{Article History:}

Received 1 January 2019

Accepted 18 February 2019

Available online 19 March 2019

\section{ABSTRACT}

\begin{abstract}
Since we entered the new century, development of science and society has raised up demand for educational level, especially for mathematics education. However, students still have low interests in mathematics learning, and mathematics-teaching models are unsatisfied. It is a top priority to improve students' interest in mathematics. This paper studies problem-teaching model introduces the idea, features, developing stages and mainstream forms of problem-based teaching. Based on the features of problem-based teaching model, this paper carries out a research on students and teachers of a middle high school in Beijing. Using questionnaire, comparative analysis and mathematical modeling and computation, this paper investigates the application of problem-based teaching in mathematics teaching. Results show that such teaching model can greatly improve students' performance in classroom, their grades, and their interests in mathematics. This paper gives suggestions to teachers on how to choose teaching methods, improve students' interests in learning and their grades.
\end{abstract}

\section{KEYWORDS}

Problem-based teaching, secondary school mathematics, situation teaching, teaching model.

\section{INTRODUCTION}

Development of science and society has raised up demand for educational level, especially for mathematics education. At present, teaching means more than imparting knowledge to students. Teachers are supposed to make further extensions in order to broaden students' views and to sparkle their passion about learning. Consequently, students can learn how to study, find problems and solve problems. Some researchers believe that problem-based teaching is learning that is based on problems [1]. Before the class, teachers need to ask questions related to the learning contents as a way to stimulate students' interest, thereby constructing an environment to empower learning and teaching students how to use what they have learnt in problem-solving.

In this way, students' learning capacity, problem-solving abilities can be greatly improved [1]. Zhang Y holds that the problems in mathematics lie in that students can learn in real problems, instead of abstract geometric and algebra questions. This kind of learning is targeted and practical. However, teachers are required to correctly lead and organize their course, and apply some strategies [2]. Different from the traditional teaching models accepted by students for long, the concept proposed by Yan L U is that the core of learning is question in question-based learning. Students ponder over the principles of questions, construct new knowledge framework, and grasp basic knowledge based on questions asked by teachers. This model is designed to cultivate students' thinking, operational abilities and independently learning abilities, instead of basic skills to solve questions and pass examinations [3]. According to WANG Lili, problem-based learning highlights place learning in a real and complicated question-based context. Helping students foster the ability to solve real problems and learning the underlying knowledge is the most effective and beneficial learning method [4]. In other research study, they had maintains that problem-based teaching model can complete students' knowledge framework and advanced thinking abilities, thereby better adapting to the demand of social development and education [5].

In this paper, the author studies problem-based teaching and introduces the ideas and features of problem-based education model, as well as development situation and mainstream forms. In addition, it focuses on students of middle high school in Beijing, uses questionnaire, comparison analysis and mathematical modeling computation and other methods and studies the application of problem-based teaching model in mathematical teaching. This study can facilitate teachers in finding new teaching methods.

\section{STATE OF THE ART}

\subsection{Origin of problem-based teaching}

Problem-based teaching model originated at 1980s in America. It was not until the 1990s that the method started to gain popularity in China. Unlike the traditional teaching methods targeted at examination, problem-based teaching model focuses on problem-solving, emphasizes students' independent thinking ability and problem-solving abilities, and is aimed to improve students' creative thinking, willpower and cultivation of knowledge transferring abilities [6].

According to the theories and practice of human education evolution, problem-centered learning is a type of discovery learning featuring active involvement. Mathematics is a relatively boring and abstract subject in middle high school education. Previously, mathematics are taught by asking students to memorize equations and theorem, solve a huge amount of maths questions and perfect themselves in using equations and 
theorem. Due to a monotonous teaching method, a large part of students hate mathematical or even regard it as a useless subject. However, through problem-based teaching model, students can explore the formation and development of mathematical theorem by asking and solving a variety of questions.

This method enhances students' understanding and memory of equations and theorem. They can think, communicate, deduce and solve problems in a mathematical way. Problem-based teaching is a dialogue-teaching model with explicit target, prominent topic and huge information. It entails teaching process focusing on problem solving. In other words, teachers should ask wise questions, inspire students and challenge them, as well as give answers and explanations. They should not directly show knowledge, conclusions and methods to students, but set up creative situations, ask inspiring and challenging questions, make learning more interesting and provide students with chances to practice, think and get involved. In the courses of observation, analysis, integration, comparison, trial and exploration, students learn how to study, ask, analyze and solve problems. In figure 1 , students are experiencing the open classes of problem-based teaching model [7].

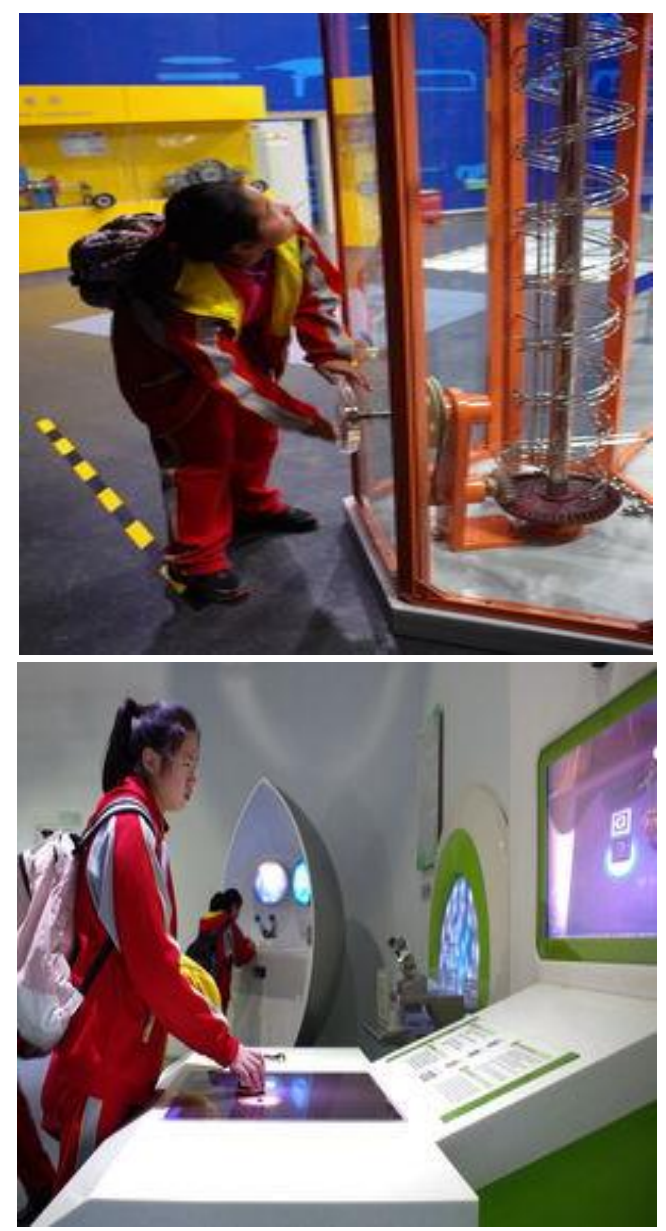

Figure 1: Students experience problems teaching mode open classroom

\subsection{Features of problem-based teaching}

Asking questions is the foundation. In problem-based teaching model, teachers put teaching goals onto a big context, lead students to find and solve problems based on real conditions and widen students' thinking. Students can thus actively investigates the knowledge behind the questions and explore various methods to solve problems. Therefore, asking questions is of great importance, for it encourages students to link new and old knowledge in a visualized and inspiring manner. Only in this way, students can have the interest to further their study and research [8].

Finding and asking questions is the core. Teachers are expected to embody teaching contents according to the requirements of textbook and students' pre-established life experience in the course of teaching. They should be able to present complicated geometric graphs into mathematical knowledge with specific connotations. Students can only grasp knowledge by applying it into real life [9]
Solving mathematical questions is a goal. Problem solving is a basic process of mathematic teaching, as well as an important section of mathematics teaching. Therefore, if students understand how to solve mathematics problems, they can learn basic knowledge and theorem better. In this process, teachers need to provide a relaxing, positive and inspiring environment, leading students to think about structures of mathematical problems, analyze preconditions of solution and encourage students to find key to these problems [10].

Applying mathematical knowledge and forming mathematical thinking is the result. In ordinary courses, teachers assume that students have understood the questions of which they can work out the answers. However, teaching goal in problem-based model not only teaches students to learn basic knowledge, but also inspires students to understand the rules of solving mathematical problems more thoroughly. They shall solve a type of problems through working out one of them, find solutions independently, and widen their thinking without being confined to only one method. Based on the established knowledge structure, students can solve problems through varied mathematical knowledge and methods. They can also form good learning habits and cultivate scientific spirit to keep exploring [11].

\subsection{Implementing model of problem-based teaching}

The question-based teaching model applied currently is shown in table 1 and 2:

Table 1: Dewey's five-step inquiry teaching method

\begin{tabular}{|c|c|c|c|}
\hline step & nature & teacher role & student role \\
\hline $\begin{array}{c}\text { Create } \\
\text { difficult } \\
\text { situations }\end{array}$ & $\begin{array}{l}\text { The starting } \\
\text { point of } \\
\text { thinking }\end{array}$ & $\begin{array}{l}\text { The designer, to } \\
\text { create a real } \\
\text { scenarios for } \\
\text { students in } \\
\text { bewilderment } \\
\text { doubt }\end{array}$ & $\begin{array}{l}\text { Conflict with } \\
\text { known } \\
\text { experience }\end{array}$ \\
\hline $\begin{array}{l}\text { Identify } \\
\text { problem }\end{array}$ & $\begin{array}{l}\text { Stimulus of } \\
\text { thinking }\end{array}$ & $\begin{array}{c}\text { Produce a } \\
\text { problem that } \\
\text { needs to be } \\
\text { solved urgently }\end{array}$ & $\begin{array}{c}\text { Have a strong } \\
\text { desire to } \\
\text { resolve }\end{array}$ \\
\hline $\begin{array}{c}\text { suggest a } \\
\text { hypothesis }\end{array}$ & $\begin{array}{l}\text { Use one of the } \\
\text { assumptions to } \\
\text { make a } \\
\text { solution to the } \\
\text { problem. }\end{array}$ & $\begin{array}{c}\text { Provide } \\
\text { materials and } \\
\text { information }\end{array}$ & $\begin{array}{c}\text { Through } \\
\text { observation } \\
\text { and collection } \\
\text { of materials to } \\
\text { arouse early } \\
\text { experience, } \\
\text { make all kinds } \\
\text { of } \\
\text { assumptions } \\
\text { to guess, study } \\
\text { and analysis of } \\
\text { the master }\end{array}$ \\
\hline reasoning & $\begin{array}{l}\text { Deduce the } \\
\text { result of each } \\
\text { stage }\end{array}$ & guide & $\begin{array}{l}\text { Organize and } \\
\text { list the } \\
\text { answers and } \\
\text { solutions to } \\
\text { the problem. }\end{array}$ \\
\hline verification & $\begin{array}{l}\text { To carry out } \\
\text { experimental } \\
\text { verification, } \\
\text { refute or } \\
\text { correct the } \\
\text { hypothesis }\end{array}$ & $\begin{array}{c}\text { Consultant and } \\
\text { staff }\end{array}$ & $\begin{array}{c}\text { To find out } \\
\text { whether the } \\
\text { assumption is } \\
\text { valid }\end{array}$ \\
\hline
\end{tabular}


Table 2: Babanski

\begin{tabular}{|c|c|c|}
\hline step & teacher role & student role \\
\hline $\begin{array}{c}\text { Create problem } \\
\text { situation }\end{array}$ & $\begin{array}{c}\text { The creator puts } \\
\text { forward the } \\
\text { problem, puts the } \\
\text { students in the } \\
\text { problem situation, } \\
\text { and assigns the task. }\end{array}$ & $\begin{array}{c}\text { In the problem } \\
\text { situation, to accept } \\
\text { the task, task, arouse } \\
\text { the early experience } \\
\text { and knowledge to } \\
\text { stimulate interest in } \\
\text { learning, learning to } \\
\text { form a sense of } \\
\text { responsibility }\end{array}$ \\
\hline Organize collective & $\begin{array}{c}\text { Organizers, random } \\
\text { and effective check } \\
\text { the process }\end{array}$ & $\begin{array}{c}\text { Discuss possible ways } \\
\text { to solve the problem, } \\
\text { summarize previous } \\
\text { experience and } \\
\text { knowledge, identify } \\
\text { the causes of the } \\
\text { phenomenon, explain } \\
\text { their process, and } \\
\text { choose the most } \\
\text { freasonable solution to } \\
\text { the problem. }\end{array}$ \\
\hline justify a conclusion & Ask questions & $\begin{array}{c}\text { To carry out a new } \\
\text { problem solving } \\
\text { process }\end{array}$ \\
\hline justify a conclusion \\
\hline
\end{tabular}

The five-step exploring teaching proposed by Dewey in table 1 lays emphasis on students' independent search and experience, as well as cultivating their cognitive abilities; in table 2, Babanski's model highlights the thinking to encourage students to conduct creative activities. Although they are in different forms and have different emphasis, their essence is problem-oriented, widening students' knowledge, honing their problemsolving capacities and independent thinking. These are necessary to meet the demand of social development [12].

\section{METHODOLOGY}

\subsection{Rationale of problem-based teaching model}

Just as the ordinary teaching model, problem-based teaching model evaluates students using quantitative indicators such as their grades [13]. However, the emphasis of the latter is students' logical thinking abilities, problem-solving capacities, instead of merely mathematics questions. Through analyzing the changes of students' grades, this paper sets up transfer matrix and conducts modeling computation. In the efficiency analysis of education, the proportions of students who get excellent, good, not bad, pass and not pass, is regarded as state vector, marked as $\mathrm{S}(\mathrm{t})$.

$$
S(t)=\left[\begin{array}{lllll}
x_{1}(t) & x_{2}(t) & x_{3}(t) & x_{4}(t) & x_{5}(t)
\end{array}\right]
$$

In this equation, $\mathrm{t}$ represents time. Its values are integers including $0,1,2 \ldots n$.

At the initial stage, students' state vectors are called initial vector S (0). In different period, changes of students in different grades are recorded. To find the transfer of their grades, which is marked as:

$a=\left(\begin{array}{lllll}a_{1} & a_{2} & a_{3} & a_{4} & a_{5}\end{array}\right)(2)$

Combining the transfer vector of all ranges of students leads to the following transfer matrix [14]:

$$
W=\left(\begin{array}{lllll}
a_{11} & a_{12} & a_{13} & a_{14} & a_{15} \\
a_{21} & a_{22} & a_{23} & a_{24} & a_{25} \\
a_{31} & a_{32} & a_{33} & a_{34} & a_{35} \\
a_{41} & a_{42} & a_{43} & a_{44} & a_{45} \\
a_{51} & a_{52} & a_{53} & a_{54} & a_{55}
\end{array}\right)
$$

If excellent is the teaching goal is students, $\mathrm{t}(2), \mathrm{t}(3), \mathrm{t}(4)$ and $\mathrm{t}(5)$ are the possibility of good, not bad, pass and not pass students become excellent. In this case:

$$
\begin{aligned}
& t(2)=1+a_{22} t(2)+a_{23} t(3)+a_{24} t(4)+a_{25} t(5) \\
& t(3)=1+a_{32} t(2)+a_{33} t(3)+a_{34} t(4)+a_{35} t(5) \\
& t(4)=1+a_{42} t(2)+a_{43} t(3)+a_{44} t(4)+a_{45} t(5) \\
& t(4)=1+a_{52} t(2)+a_{53} t(3)+a_{54} t(4)+a_{55} t(5)
\end{aligned}
$$

\section{RESULT ANALYSIS AND DISCUSSION}

In order to find out the effects of problem-based teaching, this paper carries out a study on 400 middle high school students and some teachers at a school in Beijing. Using document survey, interview, classroom observation and comparative study, it is found:

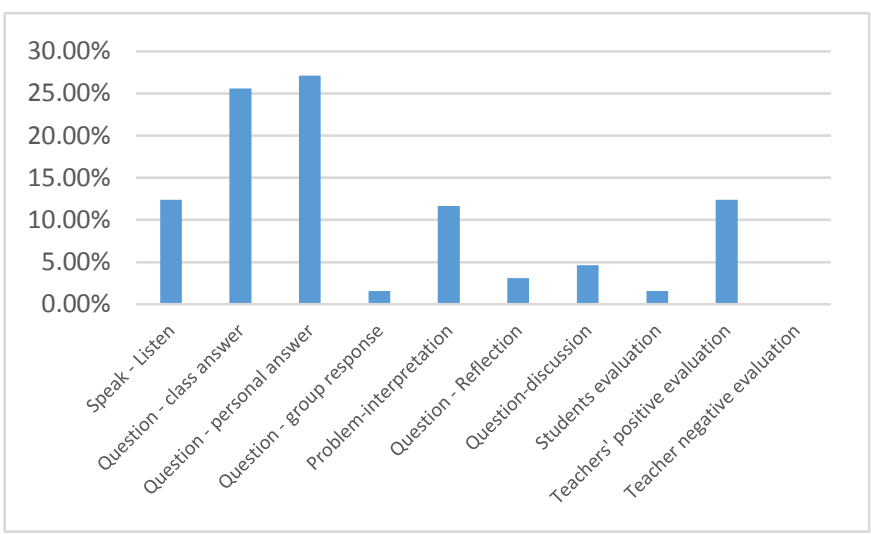

Figure 2: Analysis of classroom communication in China

As shown in figure 2, in the classroom of problem-based teaching model, students and teachers are communicating in various ways, including lecture, question to the whole class, question to an individual, question to a group, question and explanation, question and reflection, question and discussion or activity, students evaluation, teacher assessment, and other ways. This model is interactive, with the most popular form question to an individual, which can stimulate students' independent thinking and problem-solving abilities. Question to the whole class is another form that is often used. In this form, teachers ask questions to the whole class, often learners' opinion on a view [15].

Influenced by traditional teaching model, lecture still plays a quite important role in question-based teaching. Lecture is manly used by teachers to impact, explain and conclude theory and knowledge. After using many communication forms, teachers conclude theories and teach them to students in order to help them memorize. Teachers often give more positive evaluations than negative ones. It is well known that positive evaluation can help students learn knowledge, wide thinking and improve learning interests.

Question answering is a significant communication form in which students can explain their thinking to have teachers understand them. This form can perfect students' thinking, helping them apply knowledge in a more complete way. Besides the communication forms mentioned above, there are many other ways, such as discussion, reflection, student evaluation. However, they are seldom used in class, indicating that problem-based teaching is much influenced by the traditional ones, and there is still a large room for improvement. 


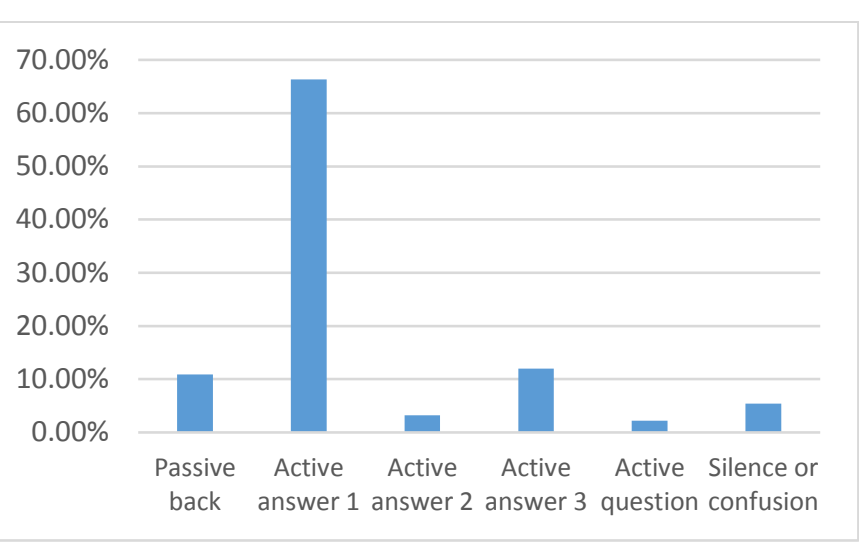

Figure 3: Analysis on the participation of students in Chinese classroom teaching

According to figure 3, the analysis on classroom involvement reveals that students are still used to answering teachers' question or give their opinions after reflection and discussion. They rarely ask their own questions, which suggests that teachers need to further activate their class and thoroughly change their present teaching model. As for students, they need to get rid of the previous learning model to think, asking and answering questions actively. In this way, they can activate their thinking, increase their knowledge and apply text knowledge into their lives.

Table 3: Research on the embodiment of learning goals in students (\%)

\begin{tabular}{|c|c|c|c|c|c|c|}
\hline \multirow{2}{*}{} & \multicolumn{3}{|c|}{ Experimental class } & \multicolumn{3}{c|}{ Non experimental class } \\
\cline { 2 - 7 } & preferably & commonly & bad & preferably & commonly & bad \\
\hline $\begin{array}{c}\text { Raise } \\
\text { questions }\end{array}$ & 34.7 & 45.3 & 20 & 20.6 & 41.1 & 38 \\
\hline $\begin{array}{c}\text { Exploration } \\
\text { problem }\end{array}$ & 31.3 & 46.8 & 21.9 & 24.0 & 44.4 & 31.6 \\
\hline $\begin{array}{c}\text { Problem } \\
\text { solving }\end{array}$ & 24.1 & 48.2 & 27.7 & 22.3 & 43.6 & 34.1 \\
\hline $\begin{array}{c}\text { cooperative } \\
\text { learning }\end{array}$ & 26.5 & 48.9 & 24.6 & 22.3 & 44.7 & 33.0 \\
\hline $\begin{array}{c}\text { Emotional } \\
\text { experience }\end{array}$ & 31.0 & 43.8 & 25.2 & 21.7 & 40.5 & 37.8 \\
\hline
\end{tabular}

From figure 3, it is found that students' in experimental class gets higher grades than control class. They are especially prominent in asking questions. In experimental class, the proportions of excellent and bad students are $34.7 \%$ and $18.2 \%$, while those in control class are $20.6 \%$ and $40.7 \%$. As far as control group is concerned, problem solving should be enhanced, as excellent students only taking up $24.1 \%$. This shows that problem-based model can be improved by enhancing the cultivation of problem-solving abilities and mathematical application abilities. This model contributes to the improvement of non-intellectual factors of students. In experimental class, students with good emotional experience account for $31 \%$, while that number is control group is $21.7 \%$.

\section{CONCLUSIONS}

Using many methods like questionnaire, comparative analysis and mathematical modeling, this paper analyzes the merits, implementation and impact of question-based mathematical model in mathematics teaching. Results show that this model helps activate students in class, increase their grades and enhance their interests in mathematics. Meantime, this paper also makes suggestions and prospect regarding the teaching model shown in this research. Question-based model can extend students' creativity and learning abilities. Problem-based education model must be popularized in a day when education requirements are growing increasingly higher. However, this paper is inevitably limited for it has no access to a wide range of resources. Future research is suggested to be done in areas of lower education level and in other subjects.

\section{REFERENCE}

[1] Chunri, L.I., Bai, Z., Zhang, X. 2013. Application of PBL of Clinical-based Problem Teaching Model in Experimental Lecture of Experimental Acupuncture Science [J]. Journal of Liaoning University of Traditional Chinese Medicine.

[2] Zhang, Y., Zhou, L., Liu, X. 2014. The effectiveness of the problem-based learning teaching model for use in introductory Chinese undergraduate medical courses: a systematic review and meta-analysis [J]. Plos One, 10 (3).

[3] Yan, L.U. 2010. Application of problem-based learning teaching model in the experimental acupuncture [J]. Journal of Shanxi Medical University.

[4] Lili, W., Weiwei, Z. 2015. Outpatient Department Office. The application of Problem-Based Learning teaching model in emergency room among nursing undergraduate interns [J]. Chinese Nursing Management.

[5] Liu, Y.L., Chen, L.L., Man-Zhen, R. 2009. The application of problembased learning approach in patient safety education among nursing students [J]. Chinese Journal of Nursing.

[6] Min, S., Ahn, Y., Lee, M. 2013. The problem-based learning integrated with simulation to improve nursing students' self-efficacy [J]. Open Journal of Nursing, 03 (1), 95-100.

[7] Liaw, S.Y., Chen, F.G., Klainin, P., O'Brien, A.P. 2009. The use of simulated learning activity in problem-based learning to improve the clinical competency of nursing students in managing a crisis event [J].

[8] Min, S., Ahn, Y., Lee, M. 2013. The problem-based learning integrated with simulation to improve nursing students' self-efficacy [J]. Open Journal of Nursing, 03 (1), 95-100.

[9] Lee, M., Ahn, Y., Cho, I. 2014. Effectiveness of Simulation Integrated with Problem Based Learning on Clinical Competency and Self-efficacy in Nursing Students [J]. Child Health Nursing Research, 20 (2), 123-131.

[10] Wong, F.K., Cheung, S., Chung, L. 2008. Framework for adopting a problem-based learning approach in a simulated clinical setting [J]. Journal of Nursing Education, 47 (11), 508-514.

[11] Wu, Q., Yue, J., Wang, J. 2014. The Application of Problem Based Learning Teaching Model in The Course Of Medical Diagnostic Imaging's Clinical Practice [J]. Chinese Journal of Coal Industry Medicine.

[12] Luo, F., Xiao-Jian, W.U., Wang, X.H. 2014. Application of Problembased Learning Teaching Model Combine with Clinical Pathway in the Clinical Practice of Hepatobiliary Surgery[J]. Northwest Medical Education.

[13] Zhang, Y.M., Wang, C.X., Zhang, N. 2015. Application of Problem-based Learning Method with the Lesson-based Learning Method in Vascular Neurology Teaching [J]. Chinese Journal of Stroke.

[14] Jingjing, L.U., Zhao, X.Q. 2015. Educational Model of Evidence-based Medicine of Vascular Neurology Based on the Open Network Platform [J]. Chinese Journal of Stroke.

[15] Yuan, J.L., Shujuan, L.I., Wenli, H.U. 2014. Attention on the Concept of Evidence-based Medicine in the Teaching of Neurology [J]. 